\title{
Isolation of Phenol-Degrading Bacteria from Decapods Mangrove Crabs
}

\author{
K. Sivasubramanian, S. Ravichandran* and P. Vigneshwaran \\ Centre of Advanced Study in Marine Biology, Annamalai University, Parangipettai-608502, Tamil Nadu, India
}

Received: December 23, 2015; Accepted: April 20, 2016; Published: April 23, 2016

*Corresponding author: S. Ravichandran, Centre of Advanced Study in Marine Biology, Annamalai University, Parangipettai- 608 502, India, Tel:+04144 243223; Exten:263; Fax:+91-4144-243555; E-mail: sravicas@gmail.com

\begin{abstract}
Phenol-degrading bacteria exist widely in the environments, and they are usually isolated from phenol contaminated site. The purpose of this study is designed to isolate the phenol degrading bacteria from gut of mangrove crab species to identify the characteristics of selected strains by various biochemical analyses. Fifteen species of mangrove crabs were collected from the five different mangrove environments (Muthupet, Pazhayar, Pichavaram, Vellar and Uppanar) located at Tamil Nadu, India. In the present study phenol degrading bacterial populations were high in the gut of Uca annulipes crabs and sediment collected from Uppanar mangrove region due to the industrial effluent in this region. Isolation of bacteria was done by culture in a mineral salt-medium containing $200 \mathrm{mg} / \mathrm{mL}$ phenol. Totally 169 strains of bacteria isolated and screened for phenol degradation in Phenol agar. Out of these isolated strains, only 8 strains (SPD1 to SPD8) were tolerating phenol at high concentration. The findings of this research indicated that gut of mangrove crabs have numerous phenol degrading bacteria such as; Pseudomonas sp., Bacillus sp., and Staphylococcus sp.
\end{abstract}

Keywords: Phenol; Degradation bacteria; Mangrove crabs; Biochemical characteristics

\section{Introduction}

Phenols are distributed as natural and artificial monoaromatic compounds in various environments [1]. Phenol and its derivatives are one of the most organic pollutants which pollute the mangrove environment considerably [2]. As reported, there are many scientists deal with phenol biodegradation by using different types of microorganisms. For example, Candida tropicalis has an ability to degrade high concentration of phenol and $C$. tropicalis can greatly remove phenolic compounds and their chlorinated derivatives in biological treatment systems with different physical configurations and process [2]. There are many bacteria and yeasts that are capable to degrade phenol at low concentration. Rhodotorula glutinis was reported to utilize phenol as sole carbon sources. It can completely degrade $5 \mathrm{mM}$ of phenol [2].

Kafilzadeh and Mokhtari, [3] reported that P. putida and Acinetobacter sp. Isolated from the mangrove sediments were the most powerful ones in phenol degradation. The most potent fungal isolate was Fennellia flavipes which isolated from the sediment of the mangrove from Savage in the Red Sea Coast, showed a highest rate of phenol degradation and the capability to degrade different phenolic compounds [4]. Other microorganisms which have been reported to degrade phenol at low concentrations included Alcaligenes eutrophus, B. stearothermophilus, Pseudomonas sp., Rhodococcus sp. and Trichosporon cutaneum [5]. The degradation of phenol with PAA-immobilized cells of P. putida with strain P8 was studied by [6]. However, several bacterial strains have been reported to degrade phenol which was isolated from the phenol polluted environments [7]. But there is no report on degradation of phenol by bacteria isolated from the gut region of mangrove crabs.

\section{Objective}

The present study was designed to isolate the phenol degrading bacteria from gut of mangrove crab species and to identify the characteristics of selected strains by various biochemical analyses.

\section{Materials and Methods}

\section{Site description}

Crabs were collected from five different mangrove regions Muthupet $\left(10^{\circ} 40^{\prime} \mathrm{N} ; 79^{\circ} 50^{\prime} \mathrm{E}\right)$, Pazhayar $\left(11^{\circ} 21^{\prime} \mathrm{N} ; 7^{\circ} 50^{\prime} \mathrm{E}\right)$,

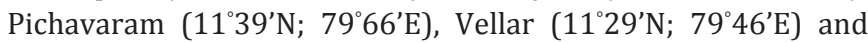
Uppanar $\left(11^{\circ} 42^{\prime} \mathrm{N} ; 7^{\circ} 46^{\prime} \mathrm{E}\right)$ along the south east coast of Tamil Nadu, India (Figure 1). These mangrove regions having industrial complex which includes of Pharmaceutical industries, fertilizers, dyes, chemicals, mineral processing plants and metal based industries. Hence the above mentioned regions receiving partially treated and untreated effluents of these industries through small channels and pipeline.

\section{Sample collection}

A total number of 15 crab species were collected from five different mangrove regions located at Tamil Nadu, India during the period between November 2012 to October 2013. Heteropanope indica were distributed in Vellar mangrove environment. The crabs Nanosesarma minutum and Neo episesarma tetragonum were available only in the following 


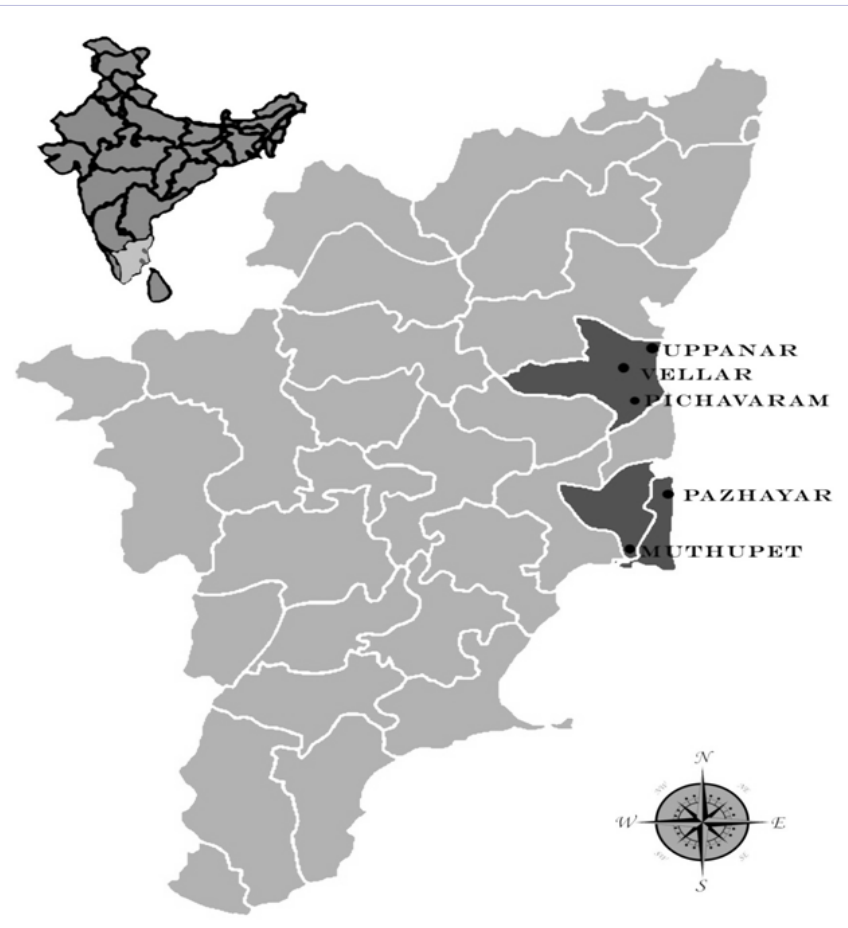

Figure 1: Map Showing the Study Area.

Pichavaram and Pazhayar mangrove environments. N. mederi, Macrophthalmus depressus, Sesarma andersoni, S. bidens, these three crabs were distributed in Pichavaram, Vellar and Uppanar mangrove environments. Among them M. messor, Metopograpsus maculatus, N. batavicum, Pseudograpsus intermedius, S. brockii, $S$. plicatum, $U$. annulipes and $U$. triangularis were distributed in all mangrove environments. Each species contained 25 individuals taken for the present study. Water and sediment samples were collected from all the five stations using sterile bottles and sterile polythene bags (approximately $100 \mathrm{ml}$ of water and $100 \mathrm{~g}$ of sediment from each site) using sterile spatula. All the samples were transported immediately to the laboratory and subjected to various analyse.

\section{Enumeration of Total bacterial load}

Gut Sample: To avoid individual variations of the gut micro flora [8], the gut of 15 species of crabs were pooled and homogenized in $10 \mathrm{ml}$ of sterile Nine-Salt Solution (NSS) [9]. Gut homogenates and water sample were diluted in NSS up to ten fold times and appropriate dilutions were spread on the surface of Zobell Marine Agar (ZMA) plates (Hi-media, Mumbai) in triplicates. The plates were incubated at $28^{\circ} \mathrm{C}$ for $24-48 \mathrm{hrs}$. The microbial load was counted and expressed as the number of Colony Forming Units (CFU).

Water and sediment Sample: After homogenizing of the collected water sample, $1 \mathrm{~mL}$ of water sample was pipetted out using a sterile pipette into a $9 \mathrm{ml}$ blank and shaken well. From this, $1 \mathrm{ml}$ was pipetted out and added to the $9 \mathrm{ml}$ blank; likewise the serial dilutions were made up to sixth dilutions and used as inoculate. From the sediment sample, $1 \mathrm{~g}$ of sediment from each station was transferred aseptically to a $99 \mathrm{ml}$ blank. The contents were homogenized for $10 \mathrm{~min}$. From this, $1 \mathrm{ml}$ was transferred aseptically to a $9 \mathrm{ml}$ blank and mixed thoroughly. Similarly serial dilutions were made and used as inoculate. Appropriate dilutions were spread on the surface of ZMA plates (Hi-media, Mumbai) in triplicate. The plates were incubated at $28^{\circ} \mathrm{C}$ for $24-48 \mathrm{hrs}$. The microbial load was counted and expressed as the number of CFU.

Isolation of phenol-degrading bacteria: The Mineral Salts Medium (MSM) was used in this study. A quantity of $1 \mathrm{~g}$ of soil sample was suspended in $100 \mathrm{~mL}$ of mineral salt medium. 200 $\mathrm{mg} / \mathrm{L}$ of phenol was used as sole source of carbon and then incubated in $250 \mathrm{~mL}$ flask at $37^{\circ} \mathrm{C}$ on rotary shaking incubator at $120 \mathrm{rpm}$ for a week [10].

The collected water samples and sediment samples were transferred aseptically to a $99 \mathrm{~mL}$ blank. For gut analysis, the digestive system was dissected out aseptically using sterile scissors and forceps and transferred to a $99 \mathrm{~mL}$ blank. Similarly serial dilutions were made and used as inoculums. Appropriately diluted samples suspensions were spread on Phenol agar plates. Cultivation was carried out for 3 days at $25^{\circ} \mathrm{C}$. The standard procedure was repeated and only isolates exhibiting pronounced growth on phenol were stored for further characterisation [11].

Characterisation of phenol-degrading bacteria: The isolates were identified based on morphological observation and biochemical characterization. The tests include gram staining, amylase, gelatinase production, citrate utilization and indole tests [10]. Bergey's manual of determinative of bacteriology was used as a reference to identify the isolates [12].

\section{Results}

\section{Bacterial load in crab gut samples}

Totally 15 species of mangrove crabs were analysed for our present study from five different stations. Of these $U$. annulipes collected from Uppanar mangrove environment showed maximum population of phenol degrading bacteria when compared to the other stations $\left(3.2 \pm 0.32 \times 10^{4} \mathrm{CFU} / \mathrm{g}\right)$ and the lowest bacterial population was found in $H$. indica $(0.3 \pm 0.32$ $\mathrm{x} 10^{4} \mathrm{CFU} / \mathrm{g}$ ) collected from Vellar. This study also suggests that no phenol degrading bacteria were present in the following crabs such as M. messor, M. maculatus, $N$. batavicum and P. intermedius (Table 1).

\section{Bacterial load in water and sediment samples}

The numbers of cultivable bacterial cells present in water and sediment samples were estimated after isolation and growth on phenol agar. In water samples, maximum heterotrophic bacterial population was found in Pichavaram mangrove $\left(1.9 \pm 0.32 \times 10^{4}\right.$ $\mathrm{CFU} / \mathrm{mL})$ followed by Vellar $\left(1.6 \pm 0.32 \times 10^{4} \mathrm{CFU} / \mathrm{mL}\right)$, Pazhayar $\left(1.2 \pm 0.32 \times 10^{4} \mathrm{CFU} / \mathrm{mL}\right)$ and Uppanar $\left(0.6 \pm 0.32 \times 10^{6} \mathrm{CFU} /\right.$ $\mathrm{mL}$ ) respectively. No phenol degrading bacteria was found in the water sample collected from the Muthupet mangrove region (Figure 2). 
Table 1: Phenol degrading Bacterial counts in the mangrove crab gut samples.

\begin{tabular}{|c|c|c|c|c|c|}
\hline \multirow{2}{*}{ Mangrove crabs } & \multicolumn{5}{|c|}{ CFU (g dry weight) ${ }^{-1} \times 10^{4}$} \\
\hline & Muthupet & Pazhayar & Pichavaram & Vellar & Uppanar \\
\hline H. indica & - & - & - & $0.3 \pm 0.12$ & - \\
\hline M. depressus & - & - & $0.8 \pm 0.32$ & $0.8 \pm 0.12$ & $0.6 \pm 0.13$ \\
\hline M. messor & - & - & - & - & - \\
\hline M. maculatus & - & - & - & - & - \\
\hline N. minutum & - & - & $1.2 \pm 0.32$ & - & - \\
\hline N. batavicum & - & - & - & - & - \\
\hline N. mederi & - & - & $1.2 \pm 0.32$ & $1.2 \pm 0.35$ & $1.2 \pm 0.18$ \\
\hline N. tetragonum & - & $1.3 \pm 0.32$ & - & - & - \\
\hline P. intermedius & - & - & - & - & - \\
\hline S. andersoni & - & - & $2.3 \pm 0.32$ & $1.5 \pm 0.47$ & $2.1 \pm 0.6$ \\
\hline S. bidens & - & - & $1.9 \pm 0.49$ & $1.3 \pm 0.12$ & $1.9 \pm 0.15$ \\
\hline S. brockii & $1.8 \pm 0.37$ & $1.7 \pm 0.11$ & $2.9 \pm 0.32$ & $2.4 \pm 0.15$ & $2.7 \pm 0.32$ \\
\hline S. plicatum & $1.2 \pm 0.33$ & $1.5 \pm 0.25$ & $2.6 \pm 0.12$ & $2.1 \pm 0.25$ & $2.0 \pm 0.15$ \\
\hline U. annulipes & $1.6 \pm 0.21$ & $1.1 \pm 0.23$ & $1.8 \pm 0.43$ & $2.4 \pm 0.28$ & $3.2 \pm 0.32$ \\
\hline U. triangularis & $0.9 \pm 0.42$ & $1.9 \pm 0.19$ & $2.3 \pm 0.52$ & $1.9 \pm 0.32$ & $3.1 \pm 0.16$ \\
\hline
\end{tabular}

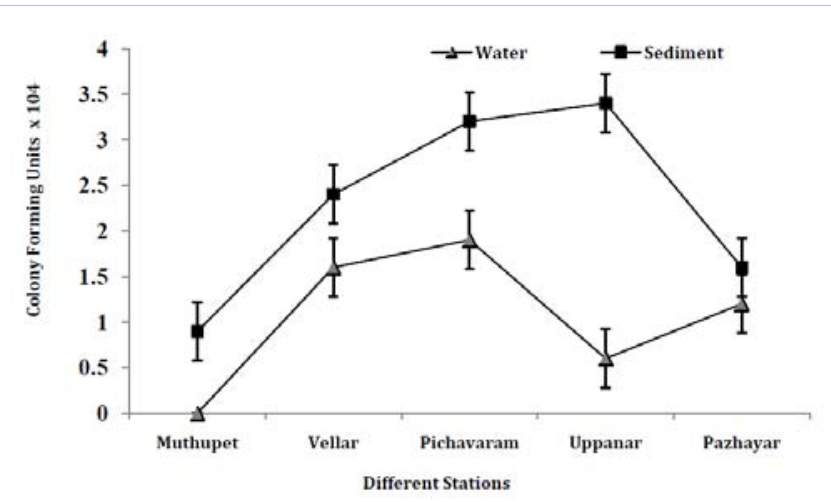

Figure 2: Bacterial Population in water and sediment samples in various mangrove environments.

In sediment samples, maximum bacterial population of $3.4 \pm$ $0.32 \times 10^{4} \mathrm{CFU} / \mathrm{g}$ was observed in Uppanar mangrove followed by Pichavaram $\left(3.2 \pm 0.32 \times 10^{4} \mathrm{CFU} / \mathrm{g}\right)$, Vellar $\left(2.4 \pm 0.32 \times 10^{4} \mathrm{CFU} /\right.$ g) and Pazhayar (1.6 $\left.\pm 0.32 \times 10^{4} \mathrm{CFU} / \mathrm{g}\right)$ respectively. Minimum bacterial population $\left(0.9 \pm 0.32 \times 10^{4} \mathrm{CFU} / \mathrm{g}\right)$ was observed in sediments collected from Muthupet mangrove environment (Figure 2).

\section{Identification of isolated bacterial strains}

Totally 169 strains of bacteria isolated from $15 \mathrm{crab}$ species collected from five different mangrove environments were screened for phenol degradation in Phenol agar. Out of these isolated strains, only eight strains (SPD1 to SPD8) (Table 2) were tolerating phenol at high concentration. These bacteria were identified by physical and biochemical characters based on Bergey's manual of bacterial identification up to generic level. Of the eight strains, six strains were identified as Bacillus sp. and one as Pseudomonas sp. and last one as Staphylococcus sp. Some strains exhibit unique biochemical characteristics that do not fit into patterns that have been used as a characteristic of any known genus and species.

\section{Discussion}

Phenol-degrading bacteria exist widely in the environments, and they are usually isolated from phenol-contaminated site. In the present study, eight phenol degrading strains, SPD 1 to SPD 8, were isolated from the genera of Pseudomonas, Bacillus and Staphylococcus. These eight strains were all isolated from the mangrove crabs collected at various stations by direct spreading plate method, in order to avoid the diversity change during the course of enrichment. The phenol tolerance of the genera Pseudomonas and Vibrio were reported to be 7-8 mM [13]. The highest phenol tolerant bacteria reported were Burkholderia cepacia PW3 and P. aeruginosa AT2 at $30 \mathrm{mM} \mathrm{[14].}$

Phenol probably exerts its toxic effects at the membrane level, as can be supported by observations that phenol changes membrane function and influences protein-to-lipid ratios in the membrane [15]. Microbes found in natural water and soil has broad ability to utilize all naturally and some synthetically occurring compounds. Their sole carbon and energy sources recycling the fixed organic carbon back into harmless biomass and carbon dioxide and resulting in clean up of environment [16]. There were reports on many microorganisms capable of degrading phenol through the action of variety of enzymes [17]. The microbial degradation of phenols, mainly by bacteria and fungi, has been extensively studied both experimentally and theoretically, but only relatively recently the capabilities of some algae for phenols biodegradation gained interest [18]. The enzymology of the degradation of phenol by Ochromonas danica was previously investigated by Semple and Cain [19].

The presence of phenol in water imparts carbolic odour to receiving water bodies and can cause toxic effects on aquatic flora and fauna [20]. It is also known to be toxic to terrestrial life including human beings [21]. Biological methods for the removal of phenol are possible because some organisms have the capacity to degrade phenol. Many scientists have isolated microorganisms from nature and obtained good degradation yields [6,22,23]. Data 


\begin{tabular}{|c|c|c|c|c|c|c|c|c|}
\hline Strain Characters & SPD1 & SPD2 & SPD3 & SPD4 & SPD5 & SPD6 & SPD7 & SPD8 \\
\hline Shape & Rod & Rod & Rod & Rod & Rod & Cocci & Rod & Rod \\
\hline Gram Stain & - & + & + & + & + & + & + & + \\
\hline Motility & + & - & - & - & - & - & - & - \\
\hline Indole & - & - & - & - & - & - & - & - \\
\hline Methyl red & - & & & & & & & \\
\hline Citrate & + & - & - & - & - & - & - & - \\
\hline Triple Sugar iron & - & + & + & + & + & + & + & + \\
\hline Catalase & + & + & + & + & + & + & + & + \\
\hline Oxidase & + & + & + & + & + & + & + & + \\
\hline Urease & - & - & - & - & - & - & - & - \\
\hline $\mathrm{H}_{2} \mathrm{~S}$ Production & - & - & - & - & - & - & - & - \\
\hline Nitrate Reduction & - & - & - & - & - & - & - & - \\
\hline Gelatinase & - & - & - & - & - & - & - & - \\
\hline Pectinase & - & - & - & - & - & - & - & - \\
\hline Identified as & Pseudomonas sp. & Bacillus sp. & Bacillus sp. & Bacillus sp. & Bacillus sp. & Staphylococcus sp. & Bacillus sp. & Bacillus s \\
\hline
\end{tabular}

were also available on the possibility of use of microorganisms for treatment of phenol bearing industrial waste water [21,24,25]. Hence, in this present investigation, attempts were made to isolate phenol degrading bacteria of sediments collected from diverse locations of mangrove regions and to select the most efficient strain.

The microorganisms convert substances such as cellulose and lignin present in the mangrove leaves into digestible matter, which is utilized by the animal communities [26-28]. In general, the initial decomposition is carried out by microorganisms like bacteria, followed by higher organisms such as crabs, and the energy is transferred to higher trophic levels [29]. Bacteria living in the gut region have the ability to digest the carbohydrates [30]. The mid gut of crabs supports good growth of proteolytic bacteria [31]. In the present study, a higher level of bacterial load was observed in the gut of $U$. annulipes and sediment collected from Uppanar mangrove region where phenol concentration were high due to untreated industrial effluent. S. brockii collected from Pichavaram mangrove region has the second high level of phenol degrading bacterial in their gut due to the organic feeding habitat of the mangrove litter rich in polyphenols.

Several studies on biological degradation of phenol have been conducted using various pure and mixed cultures of Pseudomonas sp. [32], in which, phenol is degraded via the meta-pathway [33]. The phenol degrading strain of P. putida EK II which is isolated from a soil enrichment culture can utilize phenol up to $10.6 \mathrm{mM}$ as sole source of carbon and energy. As reported, degradation of these xenobiotics was achieved only in co-metabolism with phenol under conditions of cell growth [5]. These include adapting the cells to higher phenol concentration [34], immobilization of the cells [35] and using genetically engineered microorganisms [36]. Another possible method increasing the tolerance of the cells to substrate inhibition is to supplement the growth medium with conventional carbon sources, such as yeast extract or glucose.

In this study we conclude phenol degrading bacterial populations were high in the gut of $U$. annulipes and sediment collected from Uppanar mangrove region due to the pollution of chemicals from the industrial waste which create the unsuitable for microbes survive expect the tolerating bacteria. The current study has, thus come out with an efficient, stable bacterial strains capable of degrading phenol.

\section{Acknowledgements}

Authors are thankful to the Department of Biotechnology (BT/PR5769/AAQ/3/597/2012), Government of India for the financial Support and Director of CAS in Marine Biology Annamalai University, Parangipettai for their encouragement and provided facilities.

\section{References}

1. Wang Y, Tian Y, Han B, Zhao HB, Bi JN, Cai BL. Biodegradation of phenol by free and immobilized Acinetobacter sp. strain PD12. J Environ Sci. 2007;19(2):222-5.

2. Kuo-Cheng Chen, Yun-Huin Lin, Wen-Hsiang Chen, Yi-Chun Liu Degradation of phenol by PAA-immobilized Candida tropicalis. Enzyme and Microbial Technology. 2002;31:490-497.

3. Kafilzadeh F, Mokhtari S. Isolation and Identification of Phenol Degrading Bacteria from Mangrove Sediments in the Persian Gulf (Asaluyeh) and their Growth Kinetics Assay. Biomedical \& Pharmacology Journal. 2013;6(2):189-196.

4. Aida M. Farag, Hanan M. Abd-Elnaby. Degradation of Phenol by A NewDegradable Marine Halophilic Fungus Fennellia flavipes Isolated from Mangrove Sediments. Life Science Journal. 2014;11(9).

5. Hinteregger C, Leitner R, Loidl M, Ferschl A, Streichsbier F. Degradation 
Of phenol and phenolic compounds by Pseudomonas putida EKII. Appl Microbiol Biotechnol. 1992;37(2):252-9.

6. H. Bettmann, H. J. Rehm. Degradation of phenol by Polymer Entrapped by Microorganisms. Applied Microbiology and Biotechnology. 1984;20(5):285-290

7. Guo CL, Zhou HW, Wong YS, Tam NF. Isolation of PAH-degrading bacteria from mangrove sediments and their biodegradation potential. Mar Pollut Bull. 2005;51(8-12):1054-61.

8. B Spanggaarda, I Huberb, J Nielsena, T Nielsenc, K.F Appelb, L Grama The microflora of rainbow trout intestine: a comparison of traditional and molecular identification. Aquaculture. 2000;182(1-2):1-15.

9. Olsson J, Niemczynowicz J, Bermndtsson R, Larson M. An analysis of the rainfall time structure by box counting-some practical implication. Journal of Hydrology. 1992;137(1-4):261-277.

10. Nagamani A, Soligalla R, Lowry M. Isolation and characterization of phenol degrading xanthobacter flavus. African Journal of Biotechnology. 2009;8(20):5449-5453.

11. Koutny M, Ruzicka J, Chlachula J. Screening for phenol degrading bacteria in the pristine soil of south Siberia. Applied Soil Ecology. 2003;23(1):79-83.

12. Jean F. Mac Faddin. Biochemical tests for identification of medical bacteria. Lippincott Williams \& Wilkins. London. 2000.

13. Daraktchiev R, Kolev N, Beschkov V, Aleksandrova T. A new bioreactor with a semi-fixed packing: investigation of degradation of phenol. Bioprocess Engineering. 1996;16(1):5-7.

14. El-Sayed WS, Ibrahim MK, Abu-Shady M, El-Beih F, Ohmura N, Saiki $\mathrm{H}$, et al. Isolation and characterization of phenol-catabolizing bacteria from a coking plant. Biosci Biotechnol Biochem. 2003;67(9):2026-9.

15. Sikkema J, de Bont JA, Poolman B. Mechanisms of membrane toxicity of hydrocarbons. Microbiol Rev. 1995;59(2):201-22.

16. Shah MP, Patel KA, Nair SS, Darji AM. Microbial degradation and decolourisation of Reactive Black by an application of Pseudomonas stutzeri ETL-79. OA Biotechnology. 2013;2(2):13.

17. Bhavik K. Patel, Kauresh D. Vachrajani. Pollution Status in Mangrove Ecosystem of Mahi and Dadhar River Estuaries. National Conference on Biodiversity: Status and Challenges in Conservation - 'FAVEO' 2013.

18. Lika K, Papadakis IA. Modeling the biodegradation of phenolic compounds by microalgae. Journal of Sea Research. 2009;62(23):135-146.

19. Semple KT, Cain RB. Biodegradation of phenols by the alga Ochromonas danica. Appl Environ Microbiol. 1996;62(4):1265-73.

20. Bhaskar Chandra Das, Pronoy Sinha, Kollol Mukherjee Subhasish Dutta Banik, Manas Das. Studies on removal of Phenol from contaminated water source by microbial route using Bacillus cereus. Int J Curr Res. Aca. Rev. 2014;2(1):179-184.

21. Kanekar P, Sarnaik S, Kelkar A. Microbial technology for management of phenol bearing dyestuff wastewater. Water Science and Technology. 1996;33(8):47-51.
22. Sokol W. Uptake rate phenol by Pseudomonas putida Grown in unsteady state. Biotechnol Bioeng. 1988;32(9):1097-103.

23. Antonio Lallai, Giampaolo Mura. pH variation during phenol biodegradation in mixed cultures of microorganisms. Water Research. 1989;23(11):1335-1338.

24. Kanekar P, Sarnaik S. An activated sludge process to reduce the pollution load of a dye-industry waste. Environ Pollut. 1991;70(1):2733.

25. Pradnya Kanekara, Seema Sarnaika. Microbial process for treatment of phenol bearing dye-industry effluent in a fixed film bioreactor. Journal of Environmental Science and Health. Part A. 1995;30(8):1817-1826.

26. Ravichandran S, Kannupandi T. Biochemical change in Decomposing leaves and crabs of Pichavaram mangroves. Biochemical and Cellular Archives. 2004;4(2):79-86.

27. Ravichandran S, Anthonisami A, Kannupandi T, Balasubramanian T. Habitat Preference of Crabs in Pichavaram Mangrove Environment, Southeast Coast of India. Journal of Fisheries and Aquatic Science. 2007;2(1):47-55.

28. Ravichandran S, Anthonisamy A, Kannupandi T, Balasubramanian T. Leaf choice of Herbivorous mangrove crabs. Research Journal of Environmental Sciences. 2007;1(1):26-30.

29. Ravichandran S, Ajmal Khan S, Balasubramanian T. Role of crabs in the Mangrove environment. Centre of Advanced Study in Marine biology, Annamalai University. ENVIS Publication Series. 2009;1:101.

30. Galli DR, Giese AC. Carbohydrate digestion in a herbivorous snail. Tegula funebralis. J Exp Zool. 1959;140:415-40.

31.Vankateswaran K, Sethuramalingam S, Natarajan R. Gut microflora of some edible crabs from Porto Nova coast. Ind J Mar Sci. 1981;10:399401.

32.Si-Jing Wanga, Kai-Chee Loha. Modeling the role of metabolic intermediate in kinetics of phenol biodegradation. Enzyme and Microbial Technology. 1999;25(3):177-184.

33. Sala-Trepat JM, Murray K, Williams PA. The metabolic divergence in the meta cleavage of catechols by Pseudomonas putida NCIB 10015. Physiological significance and evolutionary implications. Eur J Biochem. 1972;28(3):347-56

34. Masque C, Nolla M, Bordans A. Selection and adaptation of a phenol degrading strain of Pseudomonas. Biotechnology Letters. 1987;9(9):655-660.

35. Soda S, Ike M, Fujita M. Effect of inoculation of genetically Engineered Bacterium on performance and indigenous bacteria of sequencing batch activated sludge process treating phenol. Journal of Fermentation and Bioengineering. 1998;86(1):90-96.

36. Armenante PM, Fava F, Kafkewitz D. Effect of yeast extract on growth kinetics during aerobic biodegradation of chlorobenzoic acids. Biotechnol Bioeng. 1995;47(2):227-33. 